Andrzej GLEN

Uniwersytet Przyrodniczo-Humanistyczny w Siedlcach ${ }^{1}$

Wydzial Nauk Spolecznych/Instytut Nauk o Bezpieczeństwie

andrzej.glen@uph.edu.pl

ORCID 0000-0002-7443-2629

https://doi.org/10.34739/dsd.2020.01.01

\title{
WARTOŚCI BEZPIECZEŃSTWA PODMIOTU
}

\begin{abstract}
ABSTRAKT: W artykule, w ramach szczegółowej teorii wartości bezpieczeństwa podmiotu, kierując się regułami ogólnej teorii wartości i etyki normatywnej, zidentyfikowano i utworzono zbiór wartości bezpieczeństwo to konstytuujący. Wyprowadzono dedukcyjnie sposób istnienia i pojmowania przedmiotowych wartości. Zaproponowano metodę ich uznawania i normowania. Na utworzonym zbiorze wartości zrealizowano czynności rangujące i klasyfikujące. W rezultacie nadano wartościom bezpieczeństwa określoną rangę, i przypisano do wyróżnionych klas. Uporządkowano elementy zbioru wartości rozpinając je w strukturach sieciowej i hierarchicznej. Wreszcie sprecyzowano pojmowanie wartości we wspomnianych strukturach.
\end{abstract}

SŁOWA KLUCZOWE: bezpieczeństwo, dobro, dobrostan, wartość, cnota

\section{THE SUBJECT'S SECURITY VALUES}

ABSTRACT: The article, within the detailed theory of the subject security values, following the principles of the general theory of values and normative ethics, identifies and creates a collection of values constituting the security. Also, the subjective values' manner of existence and comprehension were deductively introduced. Moreover, the methods of their acknowledgement and standardisation were suggested. The created set of values was subject to the ranking and classifying procedures. Consequently, the security values were tiered and ascribed to the established categories. The elements of the set of values were ordered and situated within the network and hierarchic structures. Finally, the actual understanding of the values within the aforementioned constructions was defined.

KEYWORDS: security, good, well-being, value, virtue

\section{WPROWADZENIE}

Od zarania dziejów ludzie „chronili swe życie i zabezpieczali swoje najważniejsze potrzeby"2. Czynili tak by żyć, przetrwać, a także doskonalić się w sferach materialnej, ale i niematerialnej. W zapewnianiu sobie możliwości egzystencji, przetrwania i doskonalenia, kierowali się tym co dla nich dobre. Dobro to początkowo pojmowali jako „dobro dla nich samych”, a w miarę rozwoju cywilizacyjnego także jako „dobro wspólne” dla coraz zakresowo większych, a treściowo coraz bardziej złożonych całości zbiorowego, zorganizowanego działania

\footnotetext{
${ }^{1}$ Siedlce University of Natural Sciences and Humanities; Poland.

2 J. Hartman, Etyka. Poradnik dla grzeszników, Warszawa 2015, s. 76.
} 
ludzkiego. Całości te zmierzając do obrony i ochrony wartości życia, własności i rozwoju ich jakości ewoluowały, poczynając od rodów i hord, a kończąc na państwach ${ }^{3} \mathrm{i}$ ich integrowaniu się $\mathrm{w}$ ramach różnorakich organizacji międzynarodowych ${ }^{4}$.

Zatem, w nazwie bezpieczeństwo podmiotu jej zakresu należy upatrywać w odpowiedzi na pytanie: kogo bezpieczeństwo to dotyczy? Przytoczone argumenty, ale i wnioski wysnute z analizy filologicznej przedmiotowej nazwy pozwalają na pytanie: kogo dotyczy bezpieczeństwo podmiotu?, odpowiedzieć: dotyczy jednostki ludzkiej oraz różnorakich całości zbiorowego, zorganizowanego działania człowieka, w których do dziś zrzeszają się ludzie. Ponadto w ostatnich trzech dekadach na skutek zmian klimatycznych Ziemi, zaobserwować można w wypowiedziach dotyczących bezpieczeństwa cywilizacji ludzkiej próby ekoempatycznego upodmiotowienia $^{5}$, do tego czasu wyłącznie przedmiotowo traktowanej przyrody.

W rezultacie nazwa abstrakcyjna „bezpieczeństwo” umieszczana jest w różnych kontekstach. Nazwa ta konkretyzowana jest najczęściej podmiotowo kogo dotyczy?: człowieka, narodu, grupy społecznej, państwa, stowarzyszenia państw, społeczeństwa globalnego ${ }^{6}$ i dookreślana przedmiotowo czego dotyczy?, predykatami: militarne, ekonomiczne, polityczne, publiczne, powszechne, społeczne, kulturowe, ideologiczne, ekologiczne, informacyjne ${ }^{7}$. Ponadto bezpieczeństwo podmiotu umiejscawiane jest przestrzennie, jako: zewnętrzne, wewnętrzne albo lokalne, regionalne, międzynarodowe, globalne ${ }^{8}$ oraz czasowo jako: przeszłe, obecne, przyszłe ${ }^{9}$.

\begin{tabular}{|c|c|c|c|c|}
\hline Podmiot & Przedmiot & Przestrzeń 1. & Przestrzeń 2. & Czas \\
\hline $\begin{array}{l}\text { 1. Człowiek } \\
\text { 2. Grupa społeczna } \\
\text { 3. Naród } \\
\text { 4. Państwo } \\
\text { 5. Stowarzyszenia państw } \\
\text { 6. Społeczeństwo globalne }\end{array}$ & $\begin{array}{l}\text { 1. Militarne } \\
\text { 2. Ekonomiczne } \\
\text { 3. Polityczne } \\
\text { 4. Publiczne } \\
\text { 5. Powszechne } \\
\text { 6. Społeczne } \\
\text { 7. Kulturowe } \\
\text { 8. Ideologiczne } \\
\text { 9. Ekologiczne } \\
\text { 10. Informacyjne }\end{array}$ & $\begin{array}{l}\text { 1. Zewnętrzne } \\
2 . \\
\text { Wewnętrzne }\end{array}$ & $\begin{array}{l}\text { 1. Lokalne, } \\
\text { 2. Regionalne, } \\
\text { 3.Międzynarodowe } \\
\text { 4. Globalne }\end{array}$ & $\begin{array}{l}\text { 1. Przeszle } \\
\text { 2. Obecne } \\
\text { 3. Przyszle }\end{array}$ \\
\hline
\end{tabular}

Tabela 1. Możliwy zakres bezpieczeństwa podmiotu

Źródło: opracowanie własne

\footnotetext{
${ }^{3}$ F. Fukuyama, Historia ładu politycznego. Od czasów przedludzkich do rewolucji francuskiej, Poznań 2012, s. 71-116.

${ }^{4}$ S. Sagan, V. Serzhanova, Nauka o państwie wspótczesnym, Warszawa 2010, s. 186-199.

${ }^{5}$ L.J. Krzyżanowski, O podstawach kierowania organizacjami inaczej: paradygmaty, filozofia, dylematy, Warszawa 1999, s. 240-243.

${ }^{6}$ Vide: J. Stańczyk, Formutowanie kategorii pojęciowej bezpieczeństwa, Poznań 2017, s. 86-171, P. D. Williams, Security Studies. An Introduction, Tajlor\&Francis e-Library, 2008, s. 2-10, R. Wróblewski, Wprowadzenie do nauk o bezpieczeństwie, Siedlce 2017, s. 89, idem Bezpieczeństwo narodowe zintegrowane i zrównoważone, Siedlce 2019, s. 55-60.

7 Vide: W. Kitler, Bezpieczeństwo narodowe RP. Podstawowe kategorie, uwarunkowania, system, Warszawa 2011, s. 127-190, R. Wróblewski, Bezpieczeństwo..., op. cit., s. 77-132. B. Buzan, New Patterns of Global Security, „International Affairs”, Vol. 67, N. 3, Jul., 1991.

${ }^{8}$ J. Stańczyk, Formułowanie ..., op.cit., s. 167.

${ }_{9}^{9}$ M.D. Hills, Kluckhohn and Strodtbeck's Values Orientation Theory. Online Readings in Psychology and Culture, 4(4). https://doi.org/10.9707/2307-0919.1040, s. 5 (12.11.2019).
} 
W tabeli 1 dostrzec należy wielość pojmowania bezpieczeństwa podmiotu. Liczba ujęć kontekstowych przedmiotowego bezpieczeństwa od 360 (miejsce „Przestrzeń 1.”) do 1440 (miejsce „Przestrzeń 2.”) ulega zmniejszeniu albo zwiększeniu zależnie od podejścia autorów przede wszystkim do kategorii „Przedmiot”. Na przykład w przywołanych publikacjach od 4 sektorów bezpieczeństwa Barry Buzana, przez 10 bezpieczeństw przedmiotowych Waldemara Kitlera do 16 wymiarów przedmiotowych Ryszarda Wróblewskiego.

Jednak w każdym z wymienionych desygnatów bezpieczeństwa podmiotu i ich możliwych kombinacji, autorzy bezpieczeństwo to denotujący, do jego konotacji używają kategorii dobra wyrażanego wartościami, rzadziej cnotami, które często w naukach o bezpieczeństwie utożsamiane są z kategorią wartości. W praktyce naukowego poznania przedmiotowego bezpieczeństwa wartości te identyfikowane są quid facti? spekulacyjnie za pomocą intuicji intelektualnej wspartej słowotwórczo analizą źródłosłowia wyrazu „,bezpieczeństwo”, indukcyjnie przez sprawdzanie faktów rzeczywistości (fakty surowe), najczęściej normatywnej bezpieczeństwa podmiotu oraz filologicznie na drodze analizy zdań opisujących i wyjaśniających przedmiotowe bezpieczeństwo w teorii naukowej (fakty naukowe). Działanie takie implikuje kantowskie pytanie: quid juris? o prawomocność naukową realizowanego w opisanym trybie, raczej identyfikowania niż formowania systemu wartości bezpieczeństwa podmiotu.

Pozostawiając postawione pytanie otwartym, ale zmierzając do realizacji wartości poszukiwania prawdy w nauce, zasadnym staje się rozwiązanie problemu: jak uznawać, normować i strukturalizować wartości bezpieczeństwa podmiotu, aby nadać im atrybuty względnej uniwersalności i trwałości w licznych możliwych ujęciach przedmiotowych, przestrzennych i czasowych tegoż bezpieczeństwa? Odpowiedź na tak postawione pytanie ukierunkowuje poznawczo wstępna hipoteza robocza, w której przypuszcza się, że zbiór wartości w naukach o bezpieczeństwie należy identyfikować i tworzyć w ramach szczegółowej teorii wartości bezpieczeństwa podmiotu, a kierując się regułami ogólnej teorii wartości i etyki normatywnej, zmierzać do określenia istnienia i pojmowania wartości, trybu uznawania kogoś za wartościowego, a czegoś za wartościowe, klasyfikowania, normowania, ustalenia znaczenia i struktury wartości przedmiotowego bezpieczeństwa.

Rozwiązanie sformułowanego problemu i weryfikacja, a w rezultacie podniesienie prawdopodobieństwa postawionej hipotezy do rangi hipotezy naukowej, głównie przez wzgląd na podstawowy charakter prowadzonych badan, możliwe stało się z zastosowaniem systemu hipotetyczno, a po części asertoryczno-dedukcyjnego, w tym prawdziwościowych reguł logicznych rachunku zdań. 


\section{GENEZA ISTNIENIA I POJMOWANIA CNÓT I WARTOŚCI}

Ustalenie czym jest? i co to jest? dobro (agathón) dla osoby lub grupy, w której osoba ta funkcjonuje, tworzyło liczne trudności, skutkujące praktyczną, a w konsekwencji poznawczą sytuacją problemową. Próby rozwiązania tej ostatniej sytuacji odnotować można już w wiekach VIII-VI p.n.e, w okresie przedfilozoficznym, kiedy poszukiwano dobra rozumianego jako (aretè) sprawność, dzielność i doskonałość (perfectio), w modelach: bohatera, prostego człowieka, wojownika, obywatela, arystokraty, zwycięzcy, egzystencji człowieka $^{10}$. Każdy $\mathrm{z}$ wymienionych modeli charakteryzował inny zestaw zalet charakteru człowieka. Poszukiwanie zbioru cech osobowych, usprawniających czynienie dobra kontynuowano od czasów pierwszych filozofów Talesa i Anaksymandera (VI w. p.n.e) przez Heraklita, Pitagorasa, Ksenofanesa, Parmenidesa, Demokryta, Protagorasa, po czasy Sokratesa, Platona i Arystotelesa (V-IV w. p.n.e.).

Platon wyróżnił trzy najwyższe rodzaje wartości (summum bonum): dobro, piękno, prawda $^{11}$, a do fundamentalnych zalet charakteru zaliczył cnoty kardynalne: mądrość, męstwo, umiarkowanie i sprawiedliwość, pozwalające spełniać obywatelowi funkcje idealnego państwa. Z kolei Arystoteles w swej Etyce Nikomachejskiej zidentyfikował cnotę jako pewna dyspozycję, przez która człowiek staje się dobry i dzięki której dobrze wykonuje własne działania12. Wysiłki Platona i Arystotelesa w poznaniu dobra kontynuował w średniowieczu św. Tomasz z Akwinu, utożsamiając dobro z bytem i ustalając, że dobro jest tym czego wszyscy pożądają ${ }^{13}$. Z kolei w przeciwieństwie do akwinaty Jan Duns Szkot upatrywał stanowienia dobra we własnych, niezależnych od rozumu aktach woli, wybierających to, co rozum pokazuje jako wartościowe, godne dążeń ${ }^{14}$.

W epoce filozofii nowożytnej istotny wkład, w aspekcie tworzenia reguł formowania wartości bezpieczeństwa podmiotu, wniósł do etyki David Hume. Swą koncepcję moralności zawarł w Traktacie o naturze ludzkiej, księga III o moralności ${ }^{15}$. Wspomnianą koncepcję Hume oparł o uczucia przyjemności bądź nieprzyjemności, oddzielone od ludzkiego rozumu, które czerpią swe źródła z poczucia sprawiedliwości albo niesprawiedliwości. Zakładał, że człowiek ze swej natury jest egoistyczny zmierzający do zdobycia własności rozumianej jako dobra materialne zewnętrzne, zatem niesprawiedliwy. Natomiast dążność człowieka do zachowania posiadanych dóbr materialnych skłania go do zrzeszania się i zawierania umów społecznych gwarantujących zachowane tych dóbr. Uogólniając, poglądy etyczne Huma można uznać za antyracjonalne, subiektywistyczne, ale silnie zorientowane prospołecznie,

\footnotetext{
${ }^{10}$ S. Sobczak, Aksjologia i teleologia pedagogiki resocjalizacyjnej, Warszawa 2009, s. 22-28.

${ }^{11}$ W. Tatarkiewicz, Dzieje sześciu pojęć, Warszawa 2004, s.9.

12 Powszechna Encyklopedia Filozofii, http://www.ptta.pl/pef/pdf/c/cnotyiwady.pdf (14.11.2019).

${ }^{13}$ S. Sobczak, op. cit., s. 47.

${ }^{14}$ Ibidem, s. 48.

15 D. Hume, Traktat o naturze ludzkiej, http://bacon.umcs.lublin.pl/ lukasik/wp-content/uploads/2012/09/ Hume-traktat-o-naturze-ludzkiej.pdf. (21.11.2019).
} 
a posiadanie (własność) za jeden z atrybutów bezpieczeństwa podmiotu do dziś wymieniany pośród wartości to bezpieczeństwo konstytuujących.

$\mathrm{Z}$ kolei Immanuel Kant skłaniał się ku sceptycznemu racjonalizmowi, negującemu możliwość poznania przedmiotów na podstawie samego tylko rozumu, bez odniesienia do doświadczenia empirycznego ${ }^{16}$. Uważał, że o wartości moralnej czynu przesądza intencja postępowania zgodnie z obowiązkiem, a nie pod wpływem skłonności czy uczuć. Wolę dobra rozumiał on jako obowiązek. Obowiązek zaś jako konieczność czynu, wynikającą z poszanowania prawa, prowadzącego nawet wbrew skłonnościom do prawdziwego szczęścia. Kant wartość moralną działania $\mathrm{z}$ obowiązku upatrywał w zasadzie woli. Swe przekonania uprawomocnił naukowo wprowadzając kategorie etyczne imperatywów ${ }^{17}$, w których, między innymi, nakazywał: „Postępuj tylko według takiej maksymy, dzięki której możesz zarazem chcieć, żeby stała się prawem powszechnym lub Postępuj tak byś człowieczeństwa tak w twej osobie, jak też w osobie każdego innego używał zawsze zarazem jako celu, nigdy tylko jako środka" ${ }^{18}$. Maksymy te wykorzystał w koncepcji państwa celów, przez które Kant rozumiał systematyczne powiązanie różnych istot rozumnych przez wspólne prawa. Człowiek w takim państwie jest powszechnie prawodawczy, a zarazem podległy tym prawom, a obowiązek w państwie celów nie ciąży na zwierzchniku, ale na każdym członku. Podejście etyczne Kanta do człowieka i państwa, znalazło w przestrzeni międzynarodowej stałe miejsce wśród paradygmatów liberalnych security studiem, pod nazwami liberalizm tradycyjny lub liberalizm kantowski ${ }^{19}$.

Współczesne rozumienie teorii wartości zapoczątkował w połowie XIX wieku Rudolph Hermann Lotze, twierdząc że ,values are the key for the world of forms” ${ }^{20}$. W aksjologii R. H. Lotze wartości są niepoznawalne, człowiek je tworzy. Zatem nie istnieją obiektywnie, ale mają walor, obiektywnie obowiązują. Dobro myśliciel ten odnajduje w wartościach radości, zadowolenia i szczęścia, rozumianych jako uczucia ogólne i konieczne, stopniowane proporcjonalnie do doniosłości myśli i celów tkwiących w rzeczywistych bytach ${ }^{21}$.

Z kolei na przełomie XIX i XX wieku Franz Brentano, filozof psychologii, wprowadził do współczesnej myśli aksjologicznej intencjonalność jako właściwość aktów poznania i uczucia, kierujących człowieka ku przedmiotowi. Dobro podmiotu rozumiał jako miłość słuszną, której przeciwstawiał nienawiść. Słuszności uczucia miłości upatrywał w adekwatności do jej przedmiotu, rozumianej jako „,being appropriate, suitable, or fitting”22. Interesujące $\mathrm{w}$ aspekcie formowania wartości bezpieczeństwa podmiotu podejście do sfery wartości podmiotu wniósł neokantysta Heinrich Rickert. Pomijając jego stosunek do religii, erotyki i relacji mężczyzna-kobieta, dostrzec należy ważne i bliskie H. Lotze obiektywne

\footnotetext{
${ }^{16}$ Powszechna...., op. cit.

${ }^{17}$ I. Kant, Uzasadnienie metafizyki moralności, Kęty 2009, s. 12-32.

${ }^{18}$ Ibidem, s. 38, 46.

${ }^{19}$ P. D. Williams, op. cit., s. 30-32.

${ }^{20}$ Internet Encyclopedia of Philosophy, https://www.iep.utm.edu/ lotze/ (24.11.2019).

21 D. Sullivan, Hermann Lotze.5.3. Value Theory, Stanford Encyclopedia of Philosophy, https://plato. stanford.edu/entries/hermann-lotze/\#5.3(24.11.2019).

${ }^{22}$ Ibidem, W. Huerner, Franz Brentano, 4. Logic, Ethics, and Aestethics (24.11.2019).
} 
i jednocześnie nierealne, oddzielone od świata empirycznego istnienie wartości. W myśl przekonań Rickerta wartości pojawiają się w rzeczywistości przez wolę człowieka, a uniwersum składa się z tego co rzeczywiste i tego co wartościowe ${ }^{23}$. Natomiast Alexius Meinong z austriackiej szkoły etyków aksjologicznych we wczesnym okresie swojej aktywności naukowej przypisywał wartość do sfery emocjonalnej człowieka oraz wiązał przeżycie emocjonalne $\mathrm{z}$ rozumowym, intelektualnym ${ }^{24}$. Inny reprezentant wspomnianej szkoły Christian von Ehrenfels za wartość uważał rzecz wartą pożądania, a ponadto uzależniał istnienie wartości od przedmiotu i miary pożądania ${ }^{25}$.

Ustalenie istnienia i pojmowania wartości i cnót na potrzeby formowania wartości bezpieczeństwa podmiotu $\mathrm{w}$ całym jego zakresie wymaga ontologicznego określenia się w pojmowaniu bytu w ogóle. Wszystkie możliwe, a dokonywane przez wzgląd na przedmiot, przestrzeń i czas ujęcia kontekstowe bezpieczeństwa podmiotu wykazują jego przynależność do całości zorganizowanego zbiorowego działania ludzkiego. Człowiek wprawdzie może organizować swoje życie indywidualnie, ale prawie zawsze czyni to w ramach większej organizacji: państwa lub stowarzyszeń państw o różnym (ekonomicznym, militarnym, politycznym, ekologicznym) przeznaczeniu. Zatem w ontologii bezpieczeństwa podmiotu wydajna poznawczo staje się teoria bytu Leszka Jerzego Krzyżanowskiego ${ }^{26}$, w której zakłada on podział szeroko rozumianej rzeczywistości na dwie sfery konceptualną i realną. W sferze konceptualnej mieszczą się wszelkie byty subiektywne i intersubiektywne zawsze zależne od umysłu człowieka. Natomiast w sferze realnej wszelkie przedmioty materialne i oddziaływania materialno-energetyczno-informacyjne łączące je w większe agregaty.

W tak rozumianej rzeczywistości cnota i wartość mieszczą się w sferze konceptualnej rzeczywistości. Charakteryzuje je bytowa pochodność, niesamoistność, niesamodzielność i zależność od człowieka. Są wyobrażeniem tego co doznawane i koncepcją tego, co uznawane za godne pożądania. Wartości powstają wskutek sądu oceniającego, którego wynik jest pozytywny i wyraża aprobatę przedmiotu oceny. Przedmioty oceny mogą być częściami zarówno realnej jak i konceptualnej sfery rzeczywistości. Wartość może być zarówno uświadomiona $\mathrm{w}$ wyniku indywidualnego lub zbiorowego sądu oceniającego, ale i emocjonalnie, indywidualnie odczuwana. Zatem za wartość bezpieczeństwa podmiotu uznawany będzie wytwór odczuć, przeświadczeń lub przekonań tego podmiotu o tym co w rzeczywistości przyrodniczej, i psychospołeczno-kulturowej tegoż bezpieczeństwa jest pozytywnie oceniane i uznawane za godne pożądania i dążeń ${ }^{27}$.

Przyjęte pojmowanie wartości bezpieczeństwa podmiotu pozwala je uznać za wytwór emocji (odczucie) lub wynik myślenia w trakcie aktu poznania (przekonanie) lub doświadczenia (przeświadczenie). Jednocześnie jest ona tym, co jednostka lub środowisko społeczne tegoż

\footnotetext{
${ }^{23}$ Ibidem, A. Staiti, Heinrich Rickert, 4. The philosophy of values and the philosophy of history (24.11.2019).

${ }^{24}$ Ibidem, J. Marek, Alexius Meinong, 7.1 Meinong's Initial Theory - Value Subjectivism (24.11.2019).

${ }^{25}$ Ibidem, R. Rollinger, C. Lerna, Christian von Ehrenfels, 3. Theory of Values (24.11.2019).

${ }^{26}$ L. J. Krzyżanowski, op. cit., s. 147-171.

${ }^{27}$ Ibidem, s. 203-206.
} 
bezpieczeństwa uznaje normatywnie i powinnościowo (uznawane) za właściwy(godność pożądania) i funkcjonalny (godność dążenia) przedmiot pragnień. Natomiast za cnoty, w aspekcie bezpieczeństwie podmiotu, uznać należy zalety charakteru człowieka, uspasabiające go sprawnościowo i dyspozycyjnie do realizacji wartości składających się na dobrostan prowadzący do osiągnięcia dobra najwyższego „bezpieczeństwa” zarówno tegoż człowieka, jak i innych podmiotów. Za operacyjne $\mathrm{w}$ formowaniu wartości bezpieczeństwa podmiotu uznać można wyróżnione przez Platona cnoty kardynalne: mądrość, męstwo, umiarkowanie i sprawiedliwość. Z kolei przez dobrostan uznaje się za konsekwencjalistami listę wartości go współtworzących ${ }^{28}$, których atrybutami są jedność, miara i porządek. W wypadku bezpieczeństwa podmiotu listę tę tworzą wartości: przetrwania, integralności, niezależności i rozwoju podmiotu w środowisku wyzwań i zagrożeń tegoż bezpieczeństwa.

Wartość przyjętego w niniejszym artykule podejścia aksjologicznego i ontologicznego przejawia się $\mathrm{w}$ tworzeniu rzeczowo-atrybutowo-procesualnego pojmowania bezpieczeństwa podmiotu. Za bezpieczeństwo podmiotu $\mathrm{w}$ deklarowanym podejściu uznaje się tę część sfer realnej i konceptualnej podmiotu, w której człowiek, ludzie i wytworzone przez nich artefakty oraz zawłaszczana część przyrody (rzeczy) w procesach wzajemnego oddziaływania (procesy) tworzą wysokie prawdopodobieństwo zdarzeń pozytywnych przez co są w stanie sprostać wyzwaniom, przeciwstawić się zagrożeniom, zapewniając przetrwanie, zachowanie integralności, niezależności i rozwoju (atrybuty) tegoż podmiotu w środowisku wspomnianych wyzwań i zagrożeń. Wartości dobrostanu bezpieczeństwa podmiotu wymagają ustalenia ich znaczenia i struktury, co należy poprzedzić określeniem trybu uznania ich za wartościowe.

\section{TRYB KLASYFIKOWANIA I UZNAWANIA WARTOŚCI}

Ustalony sposób istnienia i pojmowania wartości bezpieczeństwa podmiotu pozwala uzyskać efekt ich jedności, miary i porządku, przez sądy wartości te klasyfikujące i uznające. Według kryterium źródła wartości należy je zaklasyfikować do tych odczuwanych, doświadczanych i poznawanych.

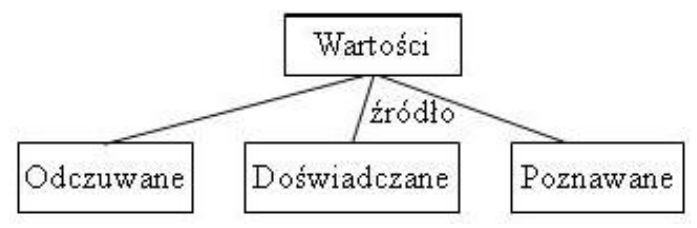

Rysunek 1. Podział wartości bezpieczeństwa podmiotu według ich źródła Źródło: opracowanie własne

Za najsilniejsze źródło identyfikacji i tworzenia tak zaklasyfikowanych wartości bezpieczeństwa podmiotu uznać należy uporządkowane językowo, metodycznie i instytucjonalnie poznanie. Człowiek wchodzi w kontakt z otaczającym go środowiskiem przez system stosunków. C.G Jung w systemie tym myślenie uznaje za główną funkcję, natomiast percepcję i intuicję

${ }^{28}$ K. Saja, Etyka normatywna. Między konsekwencjalizmem a deontologia, Kraków 2015, s. 82. 
uważa za funkcje pomocnicze, wreszcie czuciu przypisuje rangę funkcji niższej, biorącej tylko niewielki udział w poznaniu ${ }^{29}$. Zatem poznanie naukowe, którego głównym atrybutem jest myślenie staje się najbardziej wiarygodnym źródłem i zasadą jednostkowych ocen przedmiotowych wartości, a percepcji doświadczeń i uczuciom przypisać należy ważną, ale pomocniczą rolę $\mathrm{w}$ procesie poznania wartości bezpieczeństwa podmiotu.

Kolejnym istotnym kryterium klasyfikowania wartości, w aspekcie przyjętego rzeczowoatrybutowo-procesulanego pojmowania bezpieczeństwa podmiotu, jest ich osiągalność. Działanie podmiotów zmierzające do osiągnięcia dobra najwyższego - bezpieczeństwa ukierunkowuje cel działania. Natomiast za podstawowe kryterium wyznaczania celów indywidualnych i zbiorowych uznaje się wartość ${ }^{30}$. Zatem to osiągalność wartości uznać należy za główną miarę przedmiotowo określonego celu.

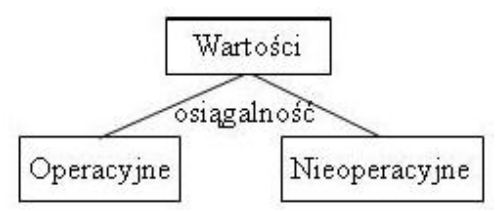

Rysunek 2. Podział wartości bezpieczeństwa podmiotu według ich osiągalności Źródło: opracowanie własne

Operacyjność wartości oznacza ich pozytywną ocenę przez wzgląd na konsekwencje dla bezpieczeństwa podmiotu $\mathrm{w}$ środowisku wyzwań i zagrożeń. Jeśli sąd oceniający wykazuje zgodność wartości $\mathrm{z}$ potrzebami otoczenia przyrodniczo-społecznego, to uznajemy ją za operacyjną, godną dążeń, spełniającą konkretną funkcję w osiąganiu celu ostatecznego bezpieczeństwa (desirable). Jeśli natomiast w ocenie podmiotu brak jest zgodności pomiędzy wartością a wspomnianymi potrzebami konieczne jest przypisanie takiej wartości do klasy nieoperacyjnej, w której mieszczą się wartości życzeniowe, nawet pożądane (desire), ale nieosiągalne ${ }^{31}$. Zatem operacyjność wartości uznaje się za kolejną zasadę ich oceny jednostkowej.

Rangowanie wartości, jak twierdzi Max Scheler tkwi w ich istocie i pozwala wyróżnić wartości wyższego i niższego rzędu. Ponadto wartości niższego rzędu są ufundowane przez wartości wyższego rządu, zatem od nich zależne bytowo. Jeśli przyjąć za kryterium rangi za M. Schelerem: trwałość, podzielność, hierarchiczność, głębokość zadowolenia z wartości i ich względność ${ }^{32}$, wyłaniają się w bezpieczeństwie podmiotu wartości najwyższe (ostateczne), dobrostanu i instrumentalne.

\footnotetext{
${ }^{29}$ J. Jacobi, Psychologia C.G. Junga, Poznań 2014, s. 44, 45.

${ }^{30}$ J. Dewey, Theory of Valuation, University of Chicago 1943, s. 33-40.

${ }^{31}$ Ibidem, s. 31, 32.

32 Z. Davis, A. Steinbock, Max Scheler, 3. Value Personalizm, Stanford Encyclopedia of Philosophy, https://plato. stanford.edu/entries/hermann-lotze/\#5.3(25.11.2019).
} 


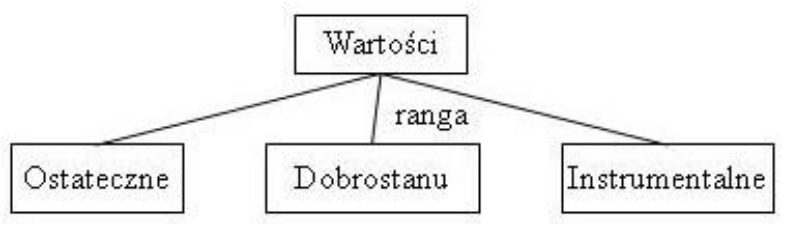

Rysunek 3. Podział wartości bezpieczeństwa podmiotu wg ich rangi Źródło: opracowanie własne

W zaprezentowanym podziale wartości bezpieczeństwa podmiotu, wartość bezpieczeństwa uznać należy za ostateczną, której atrybuty: przetrwanie, integralność, niezależność i rozwój, tworzą listę dóbr (wartości) określając jej dobrostan. Z kolei dobrostan funduje liczne wartości instrumentalne, przez które jest określany. Zatem kierując się atrybutami dobra: jednością, miarą i porządkiem rangowanie uznaje się za kolejną zasadę oceny jednostkowej wartości.

Talcott Parsons i Edward Shils w dziele pod ich redakcją poświęconym ogólnej teorii działania w poszukiwaniu wzorów osobowościowych w systemach wartości różnych społeczeństw, utworzyli alternatywne pary w układzie cech zmiennych (pattern variables), a następnie scharakteryzowali wieolaspektowo każdą z wymienionych $\operatorname{cech}^{33}$. Wzięli pod uwagę następujące pary cech: afektywne zaangażowanie - afektywną neutralność, orientację na kolektyw - orientację na własną osobę, uniwersalizm - partykularyzm, przypisanie - osiąganie oraz aspektowość - całkowitość. Potrzeba ustalenia trybu identyfikowania i tworzenia wartości bezpieczeństwa podmiotu po części może być zaspokojona przez zaliczenie po analizie pattern variables przywołanych autorów do zasad ocen jednostkowych: umiarkowanego zaangażowania afektywnego, orientacji na kolektyw, uniwersalizmu, osiągalności.

W poszukiwaniu trybu identyfikowania i tworzenia uporządkowanego zbioru wartości bezpieczeństwa podmiotu przydatna okazała się adaptacja metody szerokiej refleksyjnej równowagi Normana Danielsa ${ }^{34}$. Metodę tę z punktu widzenia etyki normatywnej, w tym teorii koherencji, precyzyjnie scharakteryzował Krzysztof Saja ${ }^{35}$. Jednak specyfika przedmiotu poznania jakim są wartości bezpieczeństwa podmiotu wymagała zastąpienia w modelu tym zasad moralnych zasadami oceny jednostkowej wartości, a jednostkowe oceny moralne jednostkowymi ocenami wartościującymi. Natomiast do teorii tła zaliczono teorie tworzone $\mathrm{w}$ ramach materialnych i formalnych nauk o bezpieczeństwie i pokrewnych dyscyplin naukowych, przede wszystkim z dziedziny nauk społecznych.

\footnotetext{
33 T. Parsons, E.A. Shils, Values, Motives, and System of Action w: T. Parsons, E.A. Shils (red) Toward a General Theory of Action, Cambrige, Massachusetts 1962, s. 76-91.

${ }^{34}$ N. Daniels, Wide Reflective Equilibrium and Theory Acceptance in Ethics, , The Journal of Philosophy, Vol. 76, No. 5 (May, 1979), pp. 256-282

${ }^{35}$ K. Saja, op. cit., s. 59-63.
} 


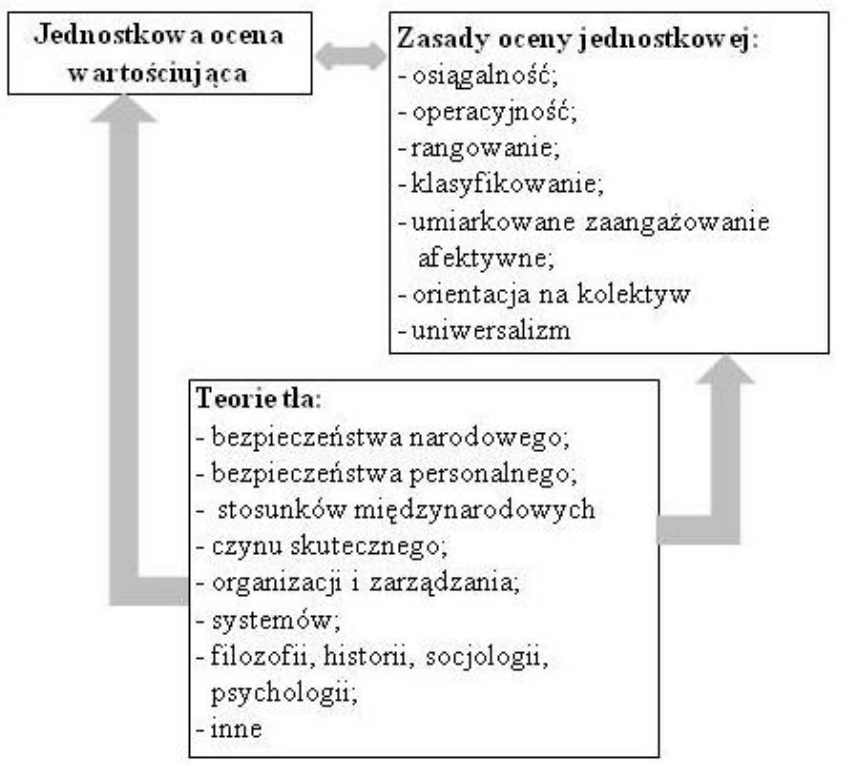

Rysunek 4. Model szerokiej refleksyjnej równowagi wartości bezpieczeństwa podmiotu Źródło: opracowanie własne

Celem metody szerokiej refleksyjnej równowagi wartości bezpieczeństwa podmiotu jest osiągnięcie koherentnego zbioru sądów wartościujących składającego się $\mathrm{z}$ rozważnych jednostkowych ocen wartościujących, rozważnych zasad ocen jednostkowych oraz istotnych teorii tworzących ich tło. Osiąganie tak postawionego celu przebiega na drodze formułowania zbioru wartości bezpieczeństwa podmiotu na podstawie implikacji wynikających z teorii tła, następnie poddawanie ich równoważeniu (sprawdzaniu) z zasadami ocen jednostkowych i wreszcie podejmowanie jednostkowych ocen wartościujących zgodnych $\mathrm{z}$ zasadami ocen jednostkowych, ale i uwzględniających implikacje teorii tła. W rezultacie znacznie zwiększa się prawdopodobieństwo sformułowania $\mathrm{w}$ trybie umiarkowanego zaangażowania afektywnego względnie uniwersalnego i trwałego zbioru wartości, charakteryzującego się osiągalnością, operacyjnością, ustaloną rangą i klasą, kolektywną orientacją. Zbioru, który ma istotne znaczenie w kreowaniu bezpieczeństwa podmiotu.

\section{USTALENIE ZNACZENIA WARTOŚCI}

Znaczenie wartości w tworzeniu bezpieczeństwa podmiotu najwyraźniej widoczne jest we wszelkich działaniach podejmowanych przez podmioty dla zapewnienia sobie wartości najwyższej - bezpieczeństwa. Sprawność tych działań w decydującej mierze zależy od poprawnej strategii działania. Ta zaś przejawia się najpełniej w kategoriach wizji, misji, interesu, i celu działania podmiotu osiągającego stan bezpieczeństwa. Natomiast sformułowanie wymienionych kategorii strategii działania podmiotu bez użycia właściwie dobranych wartości jest niemożliwe. Zatem tryb szerokiej refleksyjnej równowagi wyłaniania wartości bezpieczeństwa podmiotu jest niezwykle istotny w tworzeniu spójnego zbioru przedmiotowych wartości. Jednak dopiero określenie ich znaczenia w określaniu stanów 
końcowych (ends) oraz korzyści (interest) podmiotu z osiągnięcia tych stanów pozwala pełniej zrozumieć znaczenie wartości w bezpieczeństwie podmiotu ${ }^{36}$.

Określenie znaczenia wartości możliwe jest przez ustalenie związków między atrybutami samej wartości i elementami strategii działania w ramach bezpieczeństwa podmiotu, wspominanych już wizji, misji, interesu, celu. Natomiast organizacyjny charakter podmiotów działających w zapewnianiu swego bezpieczeństwa, skłania do przyjęcia także organizacyjnego nachylenia w pojmowaniu wymienionych elementów strategii działania. Z kolei, zgodnie z ustalonym pojmowaniem wartości za jej atrybuty uznaje się: pozytywną ocenę, pożądanie oraz godność dążeń.

Wizja rozumiana jest jako przyszły obraz fragmentu rzeczywistości utworzony przez twórczą wyobraźnię, którego zaistnienie uważa się za teoretycznie możliwe. Tak pojmowana wizja jest pożądanym obiektem dążeń bezpieczeństwa podmiotu. Zatem podmiot wyobrażający sobie obraz bezpieczeństwa podmiotu powinien brać pod uwagę funkcjonalności atrybutu wartości w relacji do atrybutów wizji. Przyszły obraz fragmentu rzeczywistości musi jednocześnie posiadać wszystkie atrybuty wartości.

Misja z kolei pojmowana jako przedmiot aspiracji, trwałych dążeń podmiotu w zakresie pożądanej społecznie jego działalności, pozwala zauważyć takie atrybuty misji jak: aspiracja, trwałe dążenie i pożądana społecznie działalność. Aspiracja jako ogół pragnień, dążeń podmiotu do osiągnięcia zamierzonego celu, społeczne uwarunkowanie tych pragnień, dążeń, w pełni absorbuje atrybuty wartości.

Najpełniej jednak kategoria wartości wykazuje swe znaczenie w kategoriach celu i interesu podmiotu zapewniającego sobie bezpieczeństwo. Cel rozumiany jest jako określony podmiotowo, przedmiotowo, przestrzennie i czasowo oczekiwany rezultat działania. Pozytywna ocena, godność pożądań i dążeń muszą pełnić rolę kryterium wyznaczania podmiotu osiągającego cel, jego przedmiotowego określenia, umiejscowienia w czasie i przestrzeni. Natomiast interes pojmuje się jako korzystny, opłacalny stan sfery materialnej i niematerialnej podmiotu, do którego podmiot ten dąży. Wartość przez swe atrybuty wykazuje, wykorzystywaną w teroii i praktyce bezpieczeństwa podmiotu zdolność pośredniczenia w ustalaniu celów i interesów przedmiotowego bezpieczeństwa. Jednak pełne rozumienie znaczenia wartości bezpieczeństwa podmiotu możliwe jest na drodze ich strukturalizowania, to znaczy połączenia relacjami wzajemnego uzupełniania się i inkluzji, pozwalającymi dostrzec hierarchię przedmiotowych wartości.

\section{STRUKTURA I CHARAKTERYSTYKA WARTOŚCI}

Przez strukturę w niniejszym opracowaniu rozumie się zbiór relacji rozpięty na zbiorze wartości przez wzgląd na ich komplementarność i inkluzywność. Sieciowość relacji wartości dobrostanu bezpieczeństwa podmiotu ilustruje rysunek 5 .

\footnotetext{
${ }^{36}$ J. Dewey, op. cit., s. 33-40.
} 


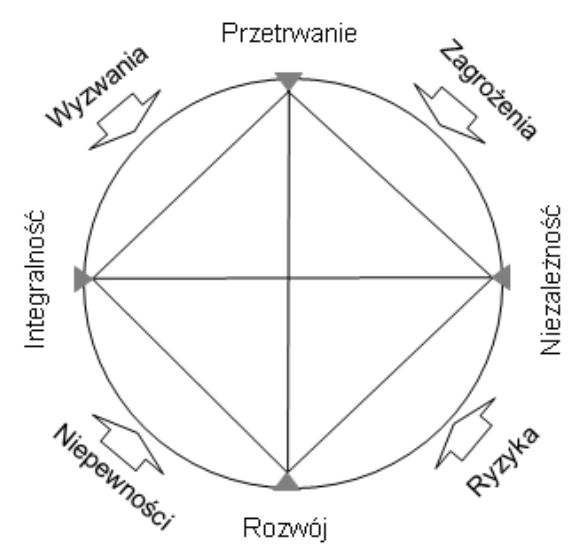

Rysunek 5. Model sieciowej struktury wartości dobrostanu bezpieczeństwa podmiotu Źródło: opracowanie własne

Na rysunku tym można dostrzec, że wyzwania i zagrożenia, ryzyko i niepewność implikują zarówno zaliczenie do zbioru dobrostanu określonych wartości, jak i relacje między nimi. Integralność pojmowana jako odporność bezpieczeństwa podmiotu na rozbicie lub nieautoryzowaną przez podmiot zmianę jego struktury warunkuje jego przetrwanie, zdolność podmiotu do niezmiennego istnienia w czasie. Ta ostania zaś w swoistym sprzężeniu zwrotnym staje się gwarantem integralności. Z kolei niezależność rozumiana jako niepodporządkowanie komuś lub czemuś, decydowanie o sobie, uniemożliwia nieautoryzowaną zmianę kształtu i uniezależnia niezmienione trwanie w funkcji czasu bezpieczeństwa podmiotu od czynników podmiotowego i przedmiotowego otoczenia tegoż bezpieczeństwa. Z kolei brak możliwości zachowania integralności i przetrwania, nie pozwala zachować niezależności bezpieczeństwa podmiotu. Wreszcie postęp w doskonaleniu się, czyli rozwój integralności, zdolności przetrwania i niezależności podmiotu warunkuje zachowanie jego bezpieczeństwa, a jednocześnie nie jest możliwy wobec podmiotu niezintegrowanego, zależnego i niezdolnego do przetrwania.

Bezpieczeństwo podmiotu jako wartość najwyższą, ostateczną funduje jego dobrostan, listę dóbr (wartości), pełniących rolę atrybutów tegoż dobrostanu. Natomiast wartości konstytuujące dobrostan bezpieczeństwa podmiotu fundują kolejne wartości, tym razem instrumentalne. $\mathrm{Na}$ rysunku 6. można dostrzec, że przetrwaniu sprzyja odporność, ostrożność, planowość, dokładność i ekologiczność, a w relacji do ekologiczności instrumentalną rolę pełnią: naturalność, zdrowie, czystość i cisza. Integralność z kolei funduje niepodzielność i stabilność, a niepodzielność konstytuuje współdziałanie i koordynacja. Atrybutami niezależności są autonomia i suwerenność. Rozwojowi sprzyja zaś doskonalenie się i ekonomiczność. Natomiast doskonalenie funduje śmiałość, energiczność, kreatywność, elastyczność i synergiczność. Wreszcie ekonomiczności sprzyjają wydajność, oszczędność, opłacalność i efektywność. 


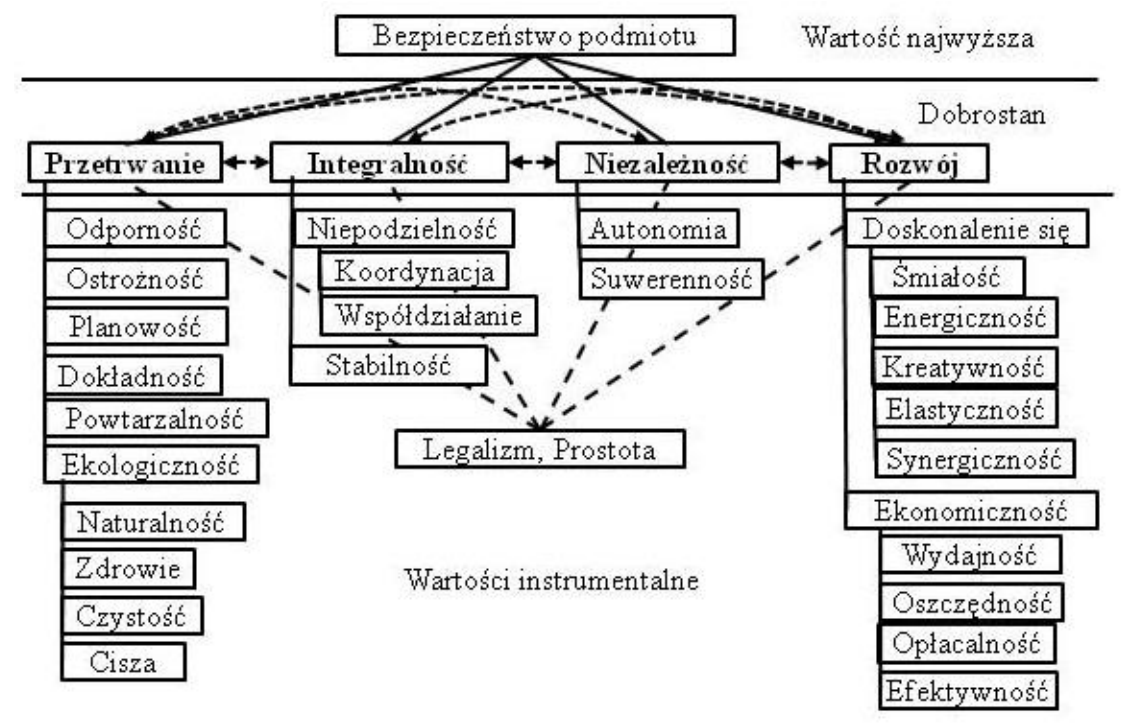

Rysunek 6. Model hierarchicznej struktury wartości dobrostanu bezpieczeństwa podmiotu.

Źródło: opracowanie własne

Przez odporność pojmuje się niepodatność podmiotu na działanie wyzwań, zagrożeń, ryzyk i niepewności. Ostrożność natomiast, jest rozumiana jako wskaźnik sprawności bezpieczeństwa podmiotu, jego przezorność i rozwaga, polegająca na zwiększeniu uwagi i dostosowaniu zachowania do warunków otoczenia w stopniu umożliwiającym odpowiednio szybkie reagowanie. $\mathrm{Z}$ kolei planowość jest przestrzeganiem w aspektach: czasowo-przestrzennych, strukturalnych i potencjałowych, typowych, wcześniej ustalonych procedur, zamierzonych działań, które miały prowadzić do sprecyzowanego celu działań bezpieczeństwa podmiotu. Natomiast za dokładność uznano miarę tego, jak wyniki pracy wykonywanej w zapewnianiu bezpieczeństwa podmiotu są bliskie jej wartości przyjętej za optymalną. Następnie za powtarzalność uznaje się zdolność do wielokrotnego wykonywania w ramach bezpieczeństwa podmiotu zaplanowanych działań w ustalonym trybie. Wartość ta gwarantuje istnienie w bezpieczeństwie podmiotu mechanizmów wymuszających ustalony tryb realizacji zadań. Ekologiczność wreszcie traktować należy jako utrzymywanie właściwych relacji między wszelkimi podmiotami angażowanymi w zapewnianie bezpieczeństwa podmiotu a otaczającym je środowiskiem naturalnym. Właściwych w znaczeniu minimalizowania szkodliwego wpływu podejmowanych działań na przyrodę.

Ekologiczności z kolei sprzyjają instrumentalnie: naturalność, zdrowie, czystość i cisza. Przez naturalność rozumiany jest poziom pozostawienia przyrody żywej i martwej w stanie pierwotnym, bez śladów wpływu człowieka na tę przyrodę. Wartość zdrowia to zdolność podmiotów do normalnego funkcjonowania w wymiarze fizycznym, psychicznym, społecznym i duchowym. Czystość z kolei to tyle, co niepowodowanie zanieczyszczeń środowiska naturalnego, a cisza traktowana jest jako stan, w którym nie rozlegają się żadne dźwięki.

W wartości integralności, niepodzielność pełni rolę tworzenia niekorzystnych warunków podziału bezpieczeństwa podmiotu, a stabilność jest utrwaloną zdolnością powracania przedmiotowego bezpieczeństwa do stanu równowagi lub pozostania podmiotu $\mathrm{w}$ stanie 
równowagi pomimo poddania go zakłóceniom, wymuszeniom. Niepodzielności bezpieczeństwa podmiotu sprzyja współdziałanie i koordynacja. Przez współdziałanie rozumiana jest zdolność do prowadzenia działań uzgodnionych w poziomie, skutkująca sytuacją, w której co najmniej jeden podmiot pomaga osiągnąć cel drugiemu podmiotowi. W tym ujęciu najwyższym poziomem pomocy dwóch podmiotów jest ich współpraca. Natomiast koordynację charakteryzuje poziom zdolności uzgadniania przez podmiot nadrzędny takiego działania podmiotów mu podległych, w którym jeden podmiot co najmniej nie przeszkadza drugiemu. W ocenie koordynacji działań podejmowanych w bezpieczeństwie podmiotu należy wziąć pod uwagę zależności przestrzenne, czasowe, kompetencyjne oraz technologiczne.

Niezależność tworzy autonomia i suwerenność podmiotu. Autonomia to możliwość stanowienia norm samemu sobie, natomiast suwerenność to zachowanie wewnętrznej i zewnętrznej niepodległości podmiotu.

Rozwój z kolei konstytuuje doskonalenie się i ekonomiczność, a doskonalenie się uzależnione jest od śmiałości, energiczności, kreatywności, elastyczności i synergiczności. Za doskonalenie uznawane jest zdobywanie coraz większych umiejętności w tworzeniu bezpieczeństwa podmiotu. Natomiast przez ekonomiczność rozumie się umiejętność racjonalnego wykorzystywania zasobów bezpieczeństwa podmiotu. Śmiałość rozumiana jest jako zdolność podmiotu do podejmowania działań obarczonych ryzykiem. Z kolei za energiczność uważa się zdolność do prowadzenia działań minimalizujących czas między bodźcem a reakcją, a nawet działań wyprzedzających. Natomiast kreatywność polega na zdolności podmiotu do tworzenia nowych idei, koncepcji lub nowych skojarzeń, powiązań z istniejącymi już ideami i koncepcjami, w celu uzyskania oryginalnych i adekwatnych do potrzeb bezpieczeństwa podmiotu rozwiązań. Synergiczność zaś to zdolność do prowadzenia wspólnych działań, uzupełniających się poprzez współpracę i synchronizację, których dodatni efekt synergiczny, wyrażający się zjawiskiem synergii, jest wyższy niż suma efektów działań indywidualnych.

Ostatnia z wartości instrumentalnych tworzących rozwój ekonomiczność, konstytuowana jest przez wydajność, oszczędność, opłacalność i efektywność. Wydajność to wskaźnik wykorzystania zasobów bezpieczeństwa podmiotu. Miarą poziomu wydajności jest proporcja efektów działań podmiotów do angażowanego potencjału (aparatura i obsługujący ją ludzie). Z kolei przez oszczędność rozumie się obniżanie kosztów działalności w ramach bezpieczeństwa podmiotu. Opłacalność zaś to przynoszenie dochodu, a przez efektywność pojmowany jest stosunek korzyści z działań bezpieczeństwa podmiotu do poniesionych na te działania nakładów (pracy, energii, materiałów itp.).

Ostatnie dwie wartości legalizm i prostota zrelatywizowane są instrumentalnie do wszystkich wartości tworzących dobrostan przedmiotowego bezpieczeństwa. Legalizm w bezpieczeństwie podmiotu jest możliwością zgodnego z prawem działania, a za prostotę uznaje się zdolność do realizacji założonych celów bez wykonywania zbędnych działań, niemających wpływu na efekt końcowy. 


\section{Podsumowanie}

Uogólniając, w niniejszym artykule ustalono w relacji do zadeklarowanego podejścia ontologicznego, że wartości bezpieczeństwa podmiotu istnieją rzeczywiście, ale subiektywnie $\mathrm{i}$ intersubiektywnie w sferze konceptualnej uniwersum bytowego. Wartości te pojmowane są jako wytwór emocji, doświadczeń i poznania ludzkiego cechujący się atrybutami: pozytywnej oceny, pożądania i godności dążeń. Natomiast za adekwatny do potrzeb poznania natury wartości, przyjęto tryb ich uznawania metodą szerokiej refleksyjnej równowagi, zaadoptowaną do potrzeb poznania przedmiotu badań. Istotą tej metody są zdania wartościujące uspójniane przez równoważenie jednostkowych ocen wartościujących z zasadami oceny jednostkowej i teoriami tła. Zauważono również, że obok wartości w aksjologii szczegółowej bezpieczeństwa podmiotu funkcjonuje kategoria cnót, które pojmowane jako zalety charakteru, sprawności podmiotu decydują wstępnie o jego dyspozycji do czynności wartościowania. Sklasyfikowano wartości bezpieczeństwa podmiotu, uzyskując ich uporządkowanie według kryteriów źródła, osiągalności i rangi. Wreszcie utworzono strukturę wartości bezpieczeństwa podmiotu, nadając im formę sieciową i hierarchiczną oraz ustalono pojmowanie wartości rozmieszczonych w tych strukturach. Można zatem uznać, że wystarczająco rozwinięto wstępną hipotezę roboczą do formy wyjaśniającej hipotezy naukowej.

Natomiast zaproponowana koncepcja aksjologiczna bezpieczeństwa podmiotu tworzy jedynie zarys pojmowania wartości przedmiotowego bezpieczeństwa. Zatem wymaga dalszych badań weryfikujących już uzyskane wyniki i poszerzających oraz pogłębiających rozumienie tak istotnych dla konstytuowania bezpieczeństwa podmiotu wartości.

\section{BIBLIOGRAFIA}

Buzan Barry. 1991. "New Patterns of Global Security in the twenty-first century". International Affairs 67 (3): 431-451.

Daniels Norman. 1979. "Wide Reflective Equilibrium and Theory Acceptance in Ethics". The Journal of Philosophy" Vol. 76 (No 5): 256-282.

Dewey John. 1943. Theory of Valuation. Chicago: University of Chicago.

Fukuyama Francis. 2012. Historia ładu politycznego. Od czasów przedludzkich do rewolucji francuskiej. Poznań: Rebis.

Hartman Jan. 2015. Etyka. Poradnik dla grzeszników. Warszawa: Agora.

Hills Michael D. 2002. Kluckhohn and Strodtbeck's Values Orientation Theory.Online Readings in Psychology and Culture, 4(4): 3-14. https://doi.org/10.9707/2307-0919.1040

Huerner Wolfgang. 2002. Franz Brentano, 4. Logic, Ethics, and Aestethics. Stanford Encyclopedia of Philosophy, https://plato. stanford.edu/.

Hume David. 2012. Traktat o naturze ludzkiej. http://bacon.umcs.lublin.pl/ lukasik/wpcontent/uploads/ 2012 /09/ Hume-traktat-o-naturze-ludzkiej.pdf.

Internet Encyclopedia of Philosophy. https://www.iep.utm.edu/ lotze.

Jacobi Jolande. 2014. Psychologia C. G. Junga. Poznań: ZYSK I S_KA. 
Kant Immanuel. 2009. Uzasadnienie metafizyki moralności. Kęty: Wydawnictwo Marek Derewiecki.

Kitler Waldemar. 2011. Bezpieczeństwo narodowe RP. Podstawowe kategorie, uwarunkowania, system. Warszawa: Wyd. AON.

Krzyżanowski Leszek Jerzy. 1999. O podstawach kierowania organizacjami inaczej: paradygmaty, filozofia, dylematy. Warszawa: PWN.

Marek Johann. 2008. Alexius Meinong, 7.1 Meinong's Initial Theory — Value Subjectivism. Stanford Encyclopedia of Philosophy, https://plato. stanford.edu/.

Parsons Talcot, Shils Edward A. 1962. Values, Motives, and System of Action w: T. Parsons, E.A. Shils (red) Toward a General Theory of Action, Cambrige, Massachusetts: 47-234. Powszechna Encyklopedia Filozofii, http://www.ptta.pl/pef/pdf.

Rollinger Robin. Lerna Carlo. 2015. Christian von Ehrenfels, 3. Theory of Values, Stanford Encyclopedia of Philosophy, https://plato. stanford.edu/.

Sagan Stanisław. Serzhanova Viktoriya. 2010. Nauka o państwie współczesnym. Warszawa: LexisNexis.

Saja Krzysztof. 2015. Etyka normatywna. Między konsekwencjalizmem a deontologią. Kraków: TAiWPN Universitas.

Schroeder Mark. 2008. Value Theory. The Stanford Encyclopedia of https://plato.stanford.edu/ entries/value-theory/.

Sobczak Sławomir. 2009. Aksjologia i teleologia pedagogiki resocjalizacyjnej. Warszawa: Wydawnictwo Pedagogium.

Staiti Andrea. 2013. Heinrich Rickert, 4. The philosophy of values and the philosophy of history. Stanford Encyclopedia of Philosophy, https://plato. stanford.edu/.

Stańczyk Jerzy. 2017. Formułowanie kategorii pojęciowej bezpieczeństwa. Poznań: FNCE.

Sullivan David. 2005. Hermann Lotze.5.3. Value Theory, Stanford Encyclopedia of Philosophy, https://plato. stanford.edu/entries/hermann-lotze/\#5.3

Tatarkiewicz Władysław. 2004. Dzieje sześciu pojęć. Warszawa: PWN.

Urban Wilbur Marshal. 1909. Valuation: its Nature and Laws. London: Swan Sonnenschein \& CO. LIM. 1909

Williams Paul D. 2008. Security Studies. An Introduction. London and New York: Routledge Tajlor\&Francis Group.

Wróblewski Ryszard. 2017. Wprowadzenie do nauk o bezpieczeństwie. Siedlce: Wyd. UPH.

Wróblewski Ryszard. 2019. Bezpieczeństwo narodowe zintegrowane i zrównoważone. Siedlce: UPH Siedlce. 